\title{
Glacial retreat and its geomorphologic effects on Mexico's active volcanoes, 1994-95
}

\author{
David Palacios, Javier de Marcos \\ Department of Physical Geography, Complutense University, E-28040 Madrid, Spain
}

\begin{abstract}
The northern slopes of Mexico's great, active stratovolcanoes, Popocatépetl (5450 m a.s.l.) and Pico de Orizaba ( $5700 \mathrm{~m}$ a.s.l.), are covered by glaciers. This paper analyzes the retreat of the glaciers between February 1994 and October 1995, and its geomorphological consequences. The results discussed are a continuation of research conducted on the volcanoes up to 1994. Although the glaciers retreated a great deal during the 1980s and early 1990s, the process accelerated from 1994 to 1995. The heavy erosion that had been observed on the deglaciated walls of the volcanoes during these decades increased as the glaciers retreated. Sediments originating from material loosened from the exposed lateral walls added to the supraglacial layer. Temperature readings taken from boreholes made in the glaciers indicated that ablation had been reduced as a result of the insulating effects of the debris mantle. This allowed widespread formation of deposits that buried ice in areas where the glacier had already disappeared. These results confirmed the conclusions of earlier studies that deglaciation of stratovolcanoes has resulted in the acceleration of slope processes and the formation of buried ice deposits.
\end{abstract}

\section{INTRODUCTION}

Popocatépetl $(5450 \mathrm{~m})$ is in the centre of the trans-Mexican volcanic belt $\left(19^{\circ} 03^{\prime} \mathrm{N}, 98^{\circ} 35^{\prime} \mathrm{W}\right)$, and Pico de Orizaba or Citlaltépetl $(5700 \mathrm{~m})$ is on the eastern edge of the range $\left(19^{\circ} \mathrm{N}, 97^{\circ} 16^{\prime} \mathrm{W}\right)$ (Fig. 1). They are the two highest volcanoes in Mexico, and are the only ones that are active and have glaciers on their slopes. Pico de Orizaba has not been volcanically active since the 17th century; Popocatépetl is more active, and ash emissions have occurred since 1994. Despite these differences, the glaciers on both volcanoes have retreated at the same rate.

Popocatépetl and Pico de Orizaba have similar morphology, including the remains of old volcanic structures that were largely destroyed when calderas formed on the northwestern slopes of the large upper volcanic cones. The remains appear on both volcanoes as rocky spurs that act as an orographical barrier against winds and insolation. This protection allows snow to accumulate where the eastern side of the spurs and the northern slopes of the cones meet.

The largest glaciers on Popocatépetl and Pico de Orizaba are located on their north faces and have formed since the last great eruptions between the 15 th and 17 th centuries. These northern glaciers evolved as a result of the sheltering effect of rocky spurs. Both glaciers advanced to their lowest altitudes at the height of the Little Ice Age, at the end of the 19th century. Except for a slight advance of their termini in the early 1970 s, the two glaciers have rapidly receded during the 20th century. A number of studies discuss the evolution of these glaciers (Lorenzo, 1964; Heine, 1975; White, 1981; Heine, 1988, 1994; Palacios 1995, 1996, in press; Palacios and Vázquez-Selem, 1996).

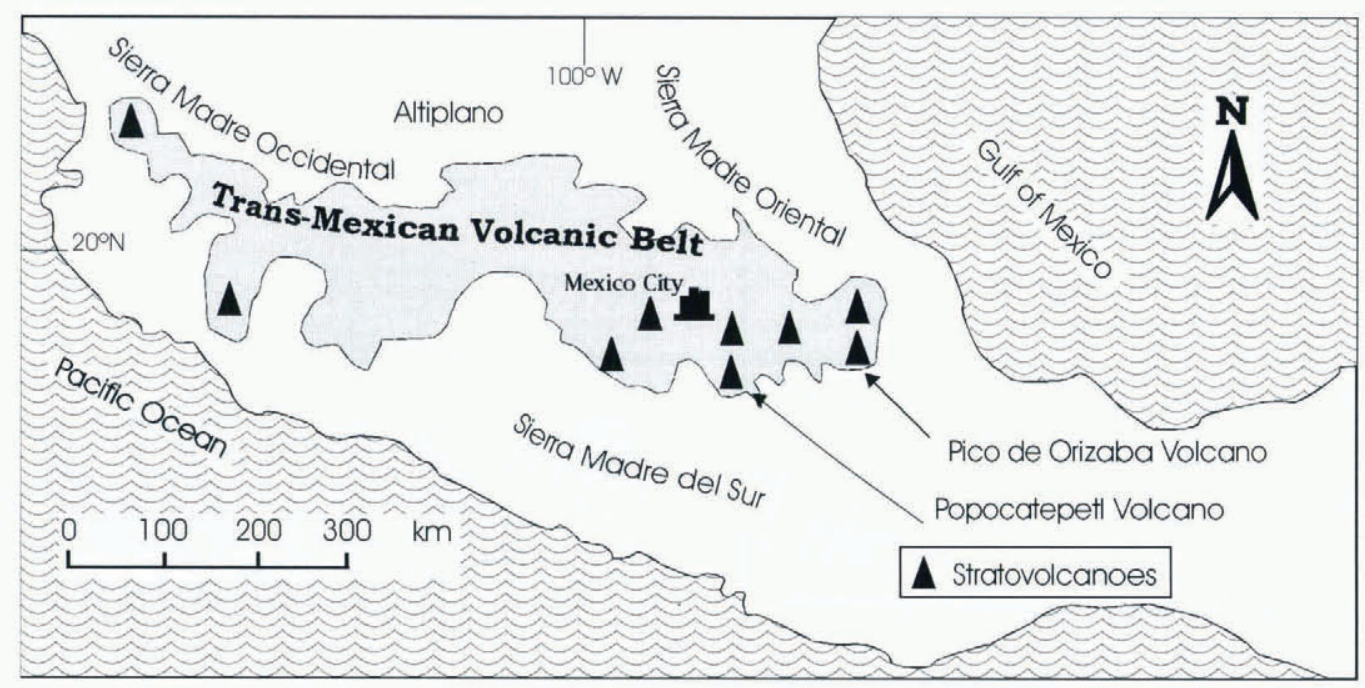

Fig. 1. Location map. 
The most recent studies completed before 1994 (Palacios, 1995, 1996, in press; Palacios and Vázquez-Selem, 1996) concluded that deglaciation exposed the eastern walls of the rocky spurs and simultaneously indicated erosional processes associated with gelifraction leading to rockfalls. As the ice retreated and erosion of the side-walls became more severe, part of the mass of ice was trapped beneath gravity deposits, thereby protecting it from insolation and melting. Eventually, this ice was isolated from the rest of the glacier.

Field observations made in February 1994 and October 1995 focused on confirming these conclusions. During this period, the retreat of the glacier terminus was carefully monitored, as was the increase of surface area of the glaciers, buried by debris. Also, temperature readings were taken on both glaciers in areas covered by debris, while in exposed areas the insulation effect of the debris mantle was also determined. Boreholes were drilled to a depth of $3 \mathrm{~m}$, and temperature readings of the ice were taken every $20 \mathrm{~cm}$.

\section{RETREAT OF THE NORTHERN GLACIER OF POPOGATÉPETL, FEBRUARY 1994-OCTOBER 1995, AND THE GEOMORPHOLOGICAL CONSE- QUENGES}

The head of Ventorrillo valley is located at $4700-4800 \mathrm{~m}$, and was exposed during the 1980s and 1990s as the northern glacier retreated (Figs 2 and 3). The spurs of Pico del Fraile form the far-western slope where lava and pyroclastic
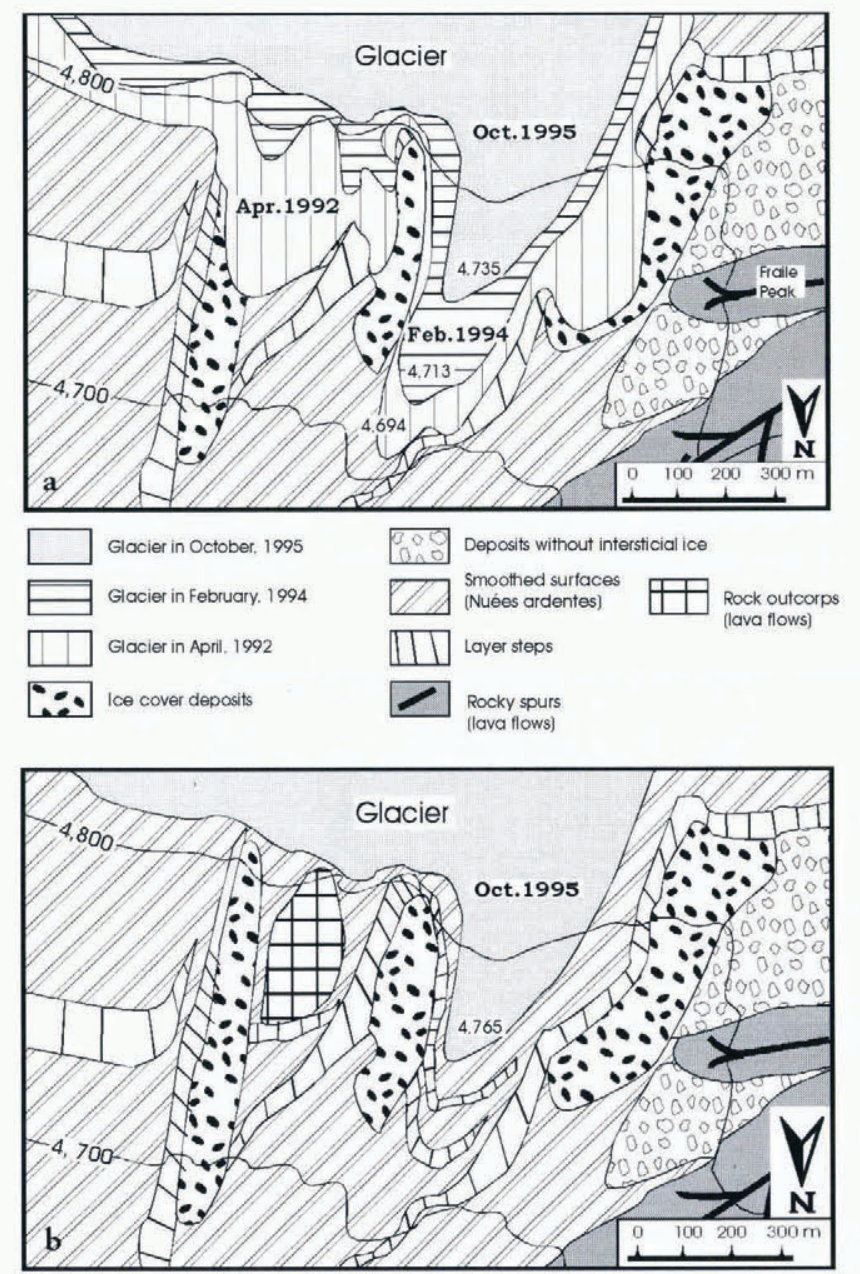

Fig. 2.. New landforms exposed following glacier retreat on Popocatépetl volcano: (a) February 1994, (b) October 1995. deposits have been uncovered, creating a very unstable environment. Rocks fall constantly and form large and very active talus slopes.

The rest of the head of the valley is formed by lava surfaces and, in particular, very compact nuées ardentes (pyroclastic flows) that have been severely abraded. Large steps $15-50 \mathrm{~m}$ high have formed where the volcanic strata come into contact with each other. In contrast to the upper surfaces, the walls of the steps have been exposed by the ice and are very unstable. Large blocks fall from the walls, and either pile up at the base or become scattered over the floor of the valley.

The glacier has retreated rapidly during the 1990s. In April 1992, it was possible to see glacier tongues that had crept along the slightly inclined lava strata and nuées ardentes to advance beyond the rest of the glacial terminus. The lowest altitude to which the glacier extended was $4694 \mathrm{~m}$. By February 1994, very little except the very thin, extreme western tongue existed at an altitude of $4713 \mathrm{~m}$. By October 1995, all of the tongues had completely disappeared except the western one, which had nonetheless receded to $4735 \mathrm{~m}$. This retreat may be linked not only to climatic con-
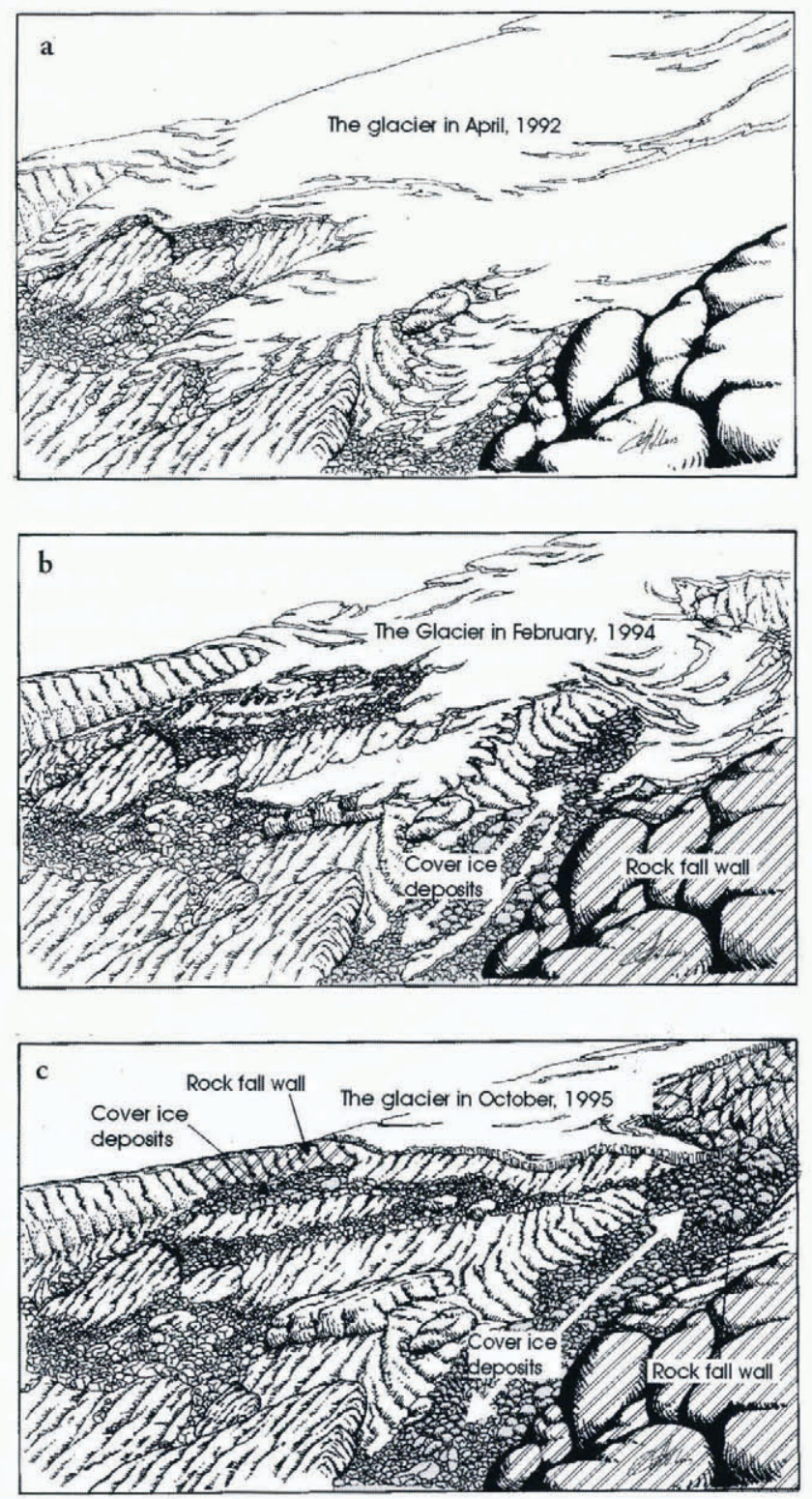

Fig. 3. Evolution of Popocatépetl northern glacier: (a) April 1992, (b) February 1994, (c) October 1995. 
ditions, but also to the volcano's increased eruptive activity that led to the glacier's being covered with ash on various occasions during the year (Delgado, in press). The warming of the glacier by the escape of hot gases and emissions of ash during several eruptions in 1994-95 may have contributed to the melting of the glacier (personal communication from S. E. White, 1997).

The steps that separate the individual volcanic strata and run the length of the valley have become exposed. An abundance of gravity-induced rock-fall activity now occurs on the steps. As the ice disappears, rock-fall talus forms at the base of the steps. This process is so intense that it has trapped part of the mass of ice stabilization under the debris, and beneath each step there is now a sedimentary formation consisting of large boulders that covers remains of the dead glacier ice. The most extensive debris-covered ice development is in the extreme western section, and is fed by falling material from the neighbouring rocky spur and the slope of Pico del Fraile.

\section{RETREAT OF GLACIAR JAMAPA (PICO DE ORIZABA VOLCANO), FEBRUARY 1994-OCTOBER 1995, AND THE GEOMORPHOLOGICAL CONSEQUENCES}

Glaciar Jamapa has retreated very rapidly during the present decade. This cannot be attributed to eruptive activity (Figs 4 and 5), but must be due to the glacier's own dynamic and climatic conditions. The tongue of Glaciar Jamapa covers a lava flow that dates from 1537 (Hoskuldsson and Robin, 1993; Hoskuldsson, 1994). This lava flow extends beyond the limits of an earlier volcanic caldera and formed a high ridge in the area, which appeared in the 1980s, due to the thinning of the glacier. The ridge was responsible for
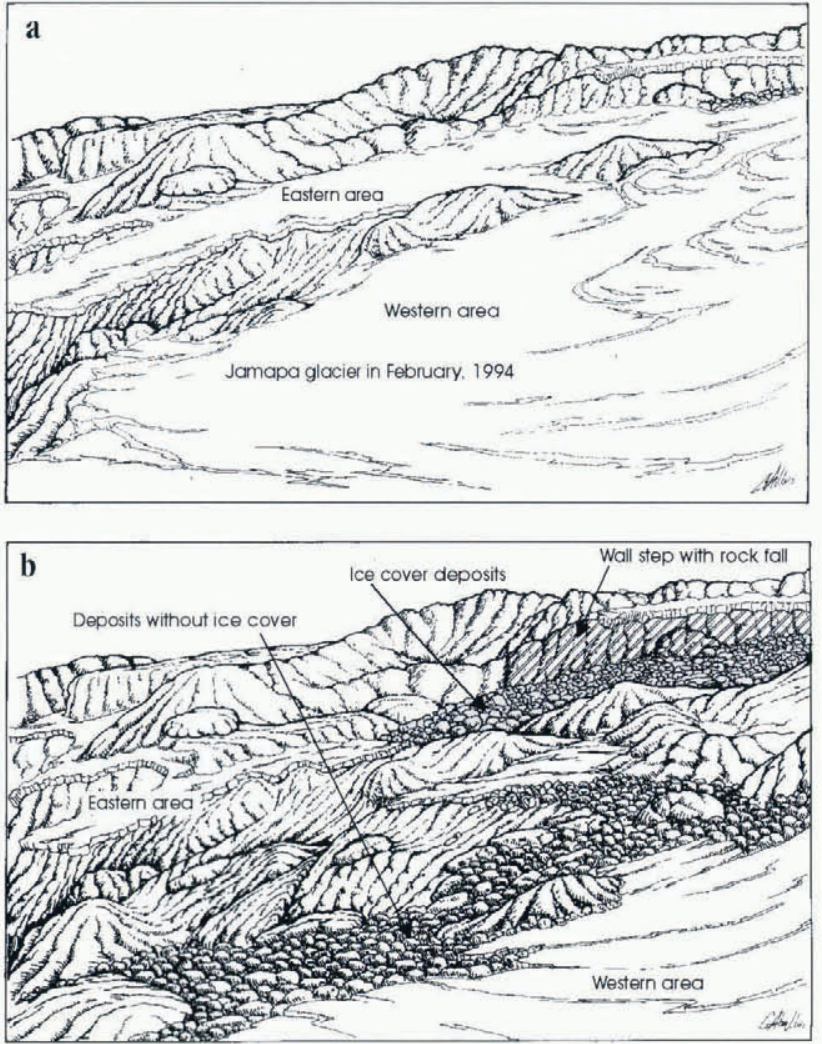

Fig. 5. Evolution of Glaciar Jamapa (Pico de Orizaba volcano): (a) February 1994, (b) October 1995.

separating the tongue of Glaciar Jamapa from the rest of the ice cap that covers the summit cone. It was following this separation that Glaciar Jamapa began to shrink drastically in volume.

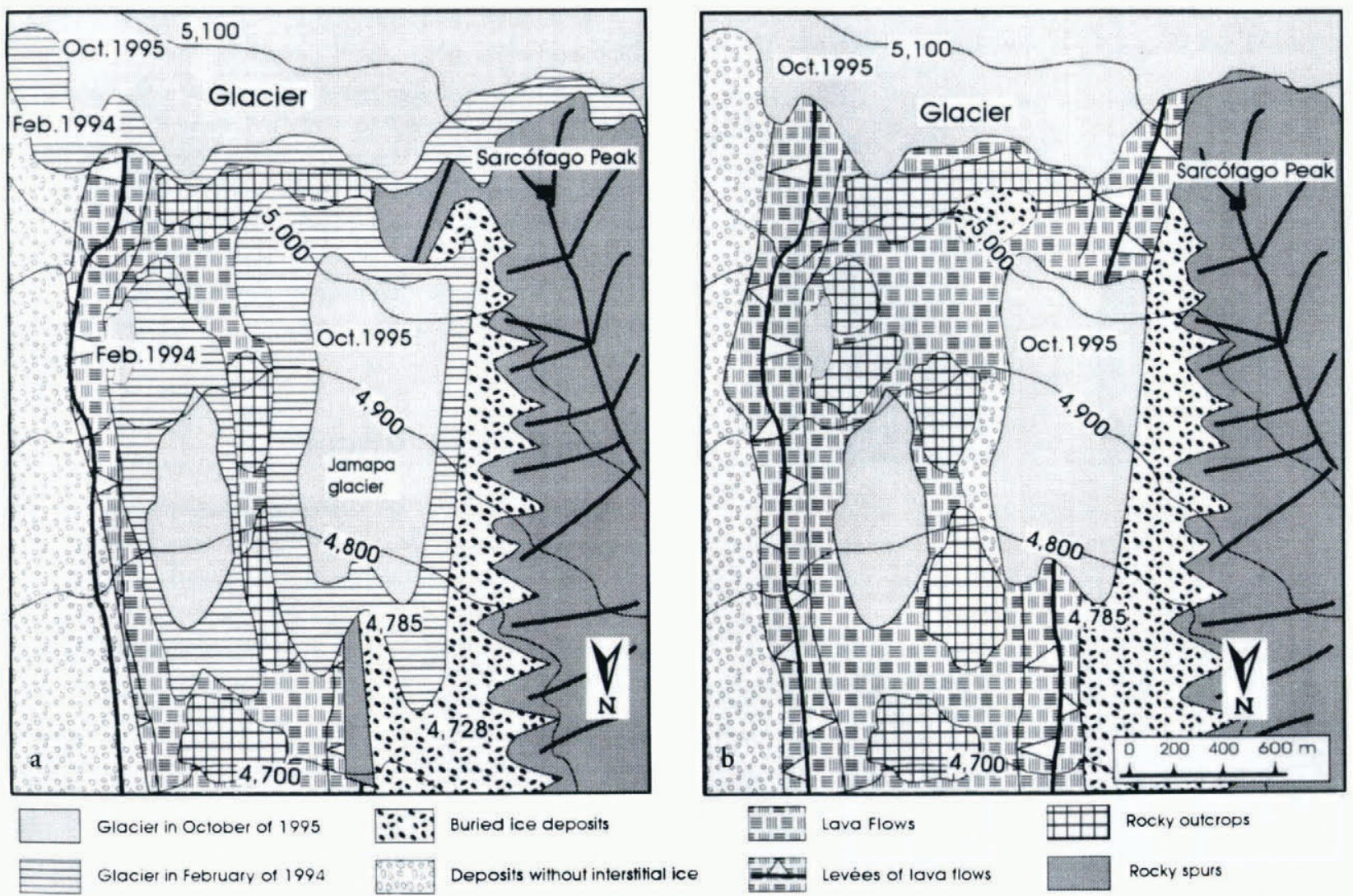

Fig. 4. New landforms exposed following glacier retreat in Pico de Orizaba volcano.: (a) February 1994, (b) October 1995. 
By February 1994, a large remnant of the glacier was divided in two by a narrow rocky outcrop. The terminus was then at $4728 \mathrm{~m}$, but by October 1995 the most eastern remnant had all but disappeared. The western section had also lost a great deal of volume, but was still relatively large.

Most of the lava flow and its distinctive levées appeared as the ice retreated. Glacial abrasion has severely eroded the lava surface. No till has been found, which supports the belief that the glacier has a small basal sediment load.

The slope of Pico del Sarcófago forms the western side of Glaciar Jamapa. Boulders break away from the slope constantly, with frequent avalanches of snow mixed with debris. The accumulation of this material forms talus that traps the remains of glacier ice (Palacios and Vázquez-Selem, 1996). This process was active in 1995, and the volume of ice-trapping talus has grown as the glacier has retreated.

\section{THERMAL CONTRAST BETWEEN GLACIER ICE AND ICE BURIED BY THE TALUS}

The talus-covered ice remains colder than the exposed glacier ice (Fig. 6), since the sedimentary material is a good insulator. This contrast was also observed during the study of Glaciar Jamapa (Palacios and Vázquez-Selem, 1996).

During October 1995, temperature readings were taken at the glaciers on Popocatépetl and Pico de Orizaba at a depth below the surface of $3 \mathrm{~m}$ and at an altitude of $4800 \mathrm{~m}$. The following results were obtained. On Popocatépetl's northern glacier the temperature dropped slightly below $0{ }^{\circ} \mathrm{C}$ up to a depth of $2.5 \mathrm{~m}$, where the temperature was $-0.7^{\circ} \mathrm{C}$. Below this depth, the temperature dropped more abruptly, and reached $-1.1^{\circ} \mathrm{C}$ at $3 \mathrm{~m}$. On Glaciar Jamapa the temperature dropped more steadily to $-1.3^{\circ} \mathrm{C}$ at $3 \mathrm{~m}$. Readings were also taken of buried ice beneath the talus on both volcanoes, also at $4800 \mathrm{~m}$. On Popocatépetl the deposits are $80 \mathrm{~cm}$ thick and the temperature at $3 \mathrm{~m}$
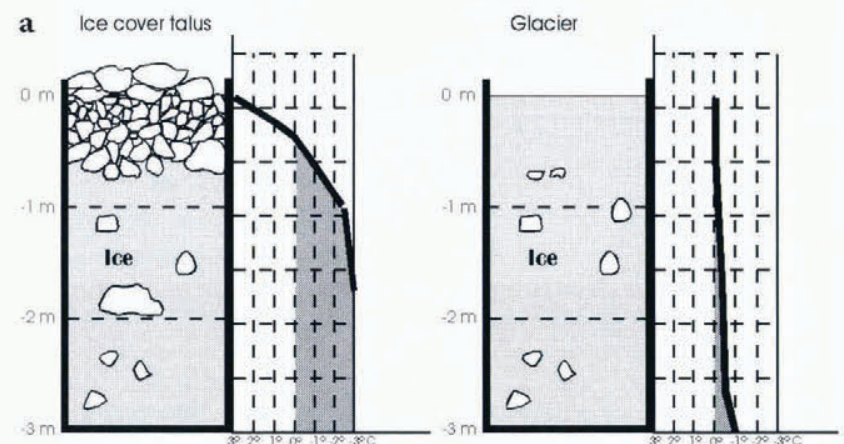

b
Ice cover talus

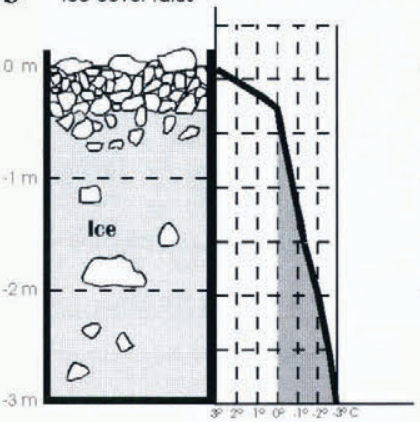

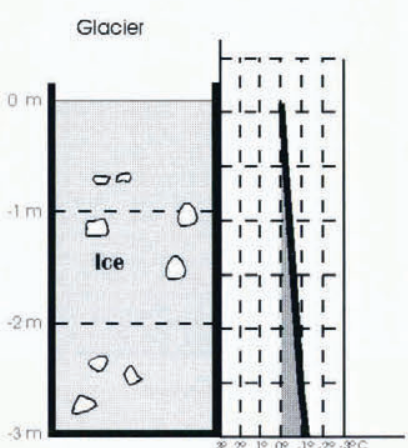

Fig. 6. Comparison of ice temperatures in glacier covered by debris and in glacier ice: (a) Popocatépetl, (b) Jamapa. was $-4.9^{\circ} \mathrm{C}$, while on Pico de Orizaba the deposits are $40 \mathrm{~cm}$ thick, and $3 \mathrm{~m}$ below the surface the temperature reached $-3^{\circ} \mathrm{C}$. This would indicate not only that the mantle of deposits helps to keep the ice at a low temperature, but that the thicker the deposit, the lower the temperature of the ice.

\section{CONCLUSIONS}

The glaciers that cover the volcanic cones of Popocatépetl and Pico de Orizaba have a low debris-load capacity. Thus, their terminal moraines, deposited during the Little Ice Age, are minimal. What little material they contain is almost exclusively the result of the glacier's bulldozing of the surface materials (Palacios, 1995; Palacios and VázquezSelem, 1996). The absence of terminal moraines and the lack of evidence of subglacial till left by the recent, rapid retreat of the ice seem to confirm this hypothesis. This lack of debris is probably due to the fact that the glacier-confining slopes contribute no debris, because they are very smooth and composed of highly permeable volcanic material that permits little glaciofluvial erosion activity. There is evidence on both volcanoes that the glaciers have little capacity to dislodge material from the rock walls that run along their lengths. Nonetheless, severe erosion takes place once these walls are exposed by receding ice. Thus, the hypothesis proposed is that release, gravity, gelifraction and, occasionally, rock-slide formation trigger the erosive activity.

The cause-and-effect relationship between the receding ice and the initiation of erosion processes is so evident that, normally, the ice that survives at the base of the wall is trapped beneath the deposits. Since the debris serves as an excellent insulator, the ice maintains a low temperature and survives. The oldest ice in these deposits is from 1971 (Heine, 1975; Palacios and Vázquez-Selem, 1996).

We believe that the rapid retreat of the glaciers between 1994 and 1995 was caused primarily by unfavourable climatic conditions, but other factors, such as the increased geothermal-heat volcano warming and volcanic activity on Popocatépetl and the appearance by glacier-thinning of a rocky spur on Pico de Orizaba, have accelerated the process. Since the glaciers on both volcanoes are now confined to the upper part of the cones where there are no outcrop features, we believe that even if the glaciers were to continue receding, there would be no further ice-cover talus formation.

\section{ACKNOWLEDGEMENTS}

The authors would like to express their thanks to the Institute of Geography of the National Autonomous University of Mexico for supporting the fieldwork. Thanks also to L. M. Tanarro and A. Gómez for their assistance in conducting fieldwork, and to A. Ferrero for translating the text into English.

\section{REFERENCES}

Delgado, H. In press. The glaciers of Popocatépetl volcano (Mexico): changes and causes. Quaternaria.

Heine, K. 1975. Permafrost am Pico de Orizaba, Mexiko. Eiszeitalter Ggw., 6, 212-217.

Heine, K. 1988. Late Quaternary glacial chronology of the Mexican volcanoes. Geowissenschaften, 6, 197-205. 
Heine, K. 1994. Past and present geocryogenic processes in Mexico. Permafrost Periglacial Proc., 5, 1-12.

Hoskuldsson, A. 1994. Le complexe volcanique Pico de Orizaba-Sierra Negra-Cerro de las Cumbres (sud-est mexicain): structure, dynamismes éruptifs et évaluation des aléas. (Thesis, Université Blaise Pascal, Clermont-Ferrand.)

Hoskuldsson, A. and C. Robin. 1993. Late Pleistocene to Holocene eruptive activity of Pico de Orizaba, eastern Mexico. Bull.Volcanol., 55, 571-587.

Lorenzo, J. L. 1964. Los glaciares de México. Second edition. México, Universidad Nacional Autónoma de México. (Monografias del Instituto de Geofisica 1.)

Palacios, D. 1995. Rockslide processes at the north slope of Popocatépetl vol- cano. Permafrost Periglacial Proc., 6 (4), 345-359.

Palacios, D. 1996. The glacio-volcanic evolution of Popocatépetl volcano: geomorphologic consequences. Geomorphology, 16, 319-335.

Palacios, D. In press. Hazards in relation to present deglaciation in Mexican stratovolcanoes; Popocatépetl, Ixtaccihuatl and Citlaltépetl. Geofournal.

Palacios, D. and L. Vázquez-Selem. 1996. Geomorphic effects of the retreat of Jamapa Glacier, Pico de Orizaba volcano (Mexico). Geogr. Ann., 78A, $19-34$.

White, S. E. 1981. Neoglacial to recent glacier fluctuations on the volcano Popocatépetl, Mexico. f. Glaciol., 27(96), 359-363.

MS received 18 October 1996 and accepted in revised form 1 July 1997 